Portland State University

PDXScholar

Dissertations and Theses

Dissertations and Theses

Spring 6-8-2018

\title{
Anti-LGB Hate Crimes: Political Threat or Political Legitimization?
}

Johanna R. Shreve

Portland State University

Follow this and additional works at: https://pdxscholar.library.pdx.edu/open_access_etds

Part of the Criminology and Criminal Justice Commons, and the Lesbian, Gay, Bisexual, and Transgender Studies Commons

Let us know how access to this document benefits you.

\section{Recommended Citation}

Shreve, Johanna R., "Anti-LGB Hate Crimes: Political Threat or Political Legitimization?" (2018).

Dissertations and Theses. Paper 4465.

https://doi.org/10.15760/etd.6349

This Thesis is brought to you for free and open access. It has been accepted for inclusion in Dissertations and Theses by an authorized administrator of PDXScholar. Please contact us if we can make this document more accessible: pdxscholar@pdx.edu. 
Anti-LGB Hate Crimes: Political Threat or Political Legitimization?

by

Johanna R. Shreve

A thesis submitted in partial fulfillment of the requirements for the degree of

\author{
Master of Science \\ in \\ Criminology and Criminal Justice
}

Thesis Committee:

Brian Renauer, Chair

Danielle McGurrin

Mark Harmon Leymon

Portland State University

2018 
(C) 2018 Johanna R. Shreve 


\begin{abstract}
While activists and others have argued that the legitimization of biased attitudes and stereotypes by political leaders foments violence against minority groups, criminological research in the U.S. has focused more on "threat" hypotheses that view hate crime as a retaliatory response to perceived gains or encroachment of targeted groups. Another view suggests that heightened public visibility of hate crimes or other bias issues, usually in the form of media coverage, increases hate crimes. This study compares the effect on anti-LGB crimes of events representing political threat (a court decision legalizing marriage equality) and political legitimization of bias (passage of a ban on marriage equality), both of which occurred in California in 2008. The study also tests effects of media coverage prior to the ban on marriage equality. Results showed a statistically significant increase in anti-LGB hate crimes after the ban on same-sex marriage. There was no effect on anti-LGB crime counts after the court decision to legalize marriage equality, or during the media campaign leading up to the vote to ban marriage equality.
\end{abstract}




\section{Table of Contents}

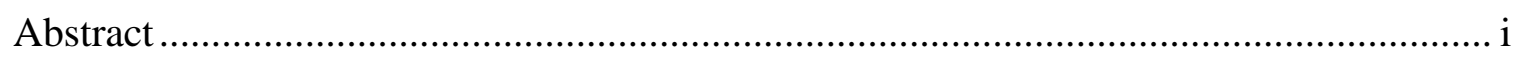

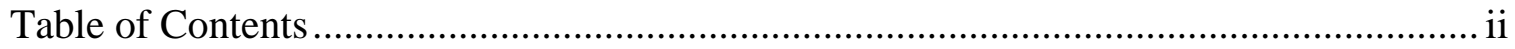

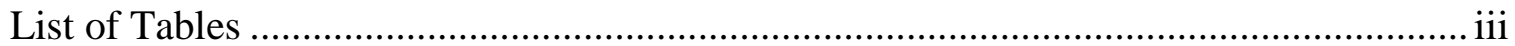

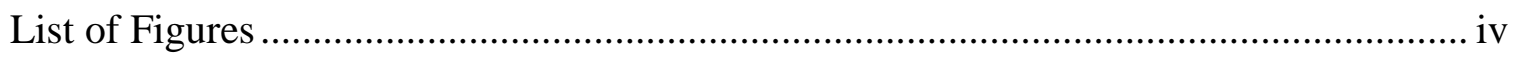

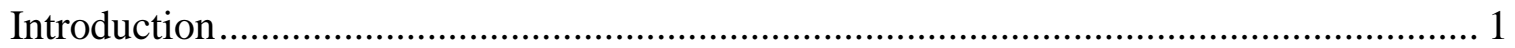

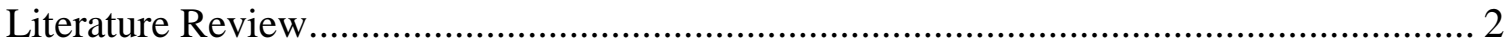

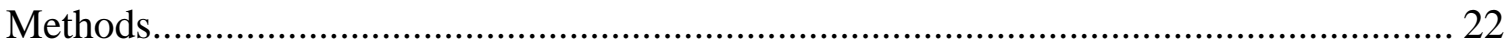

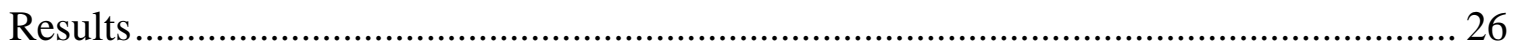

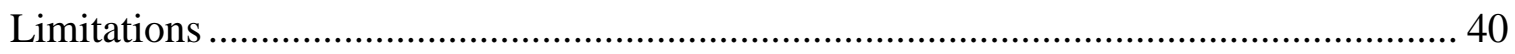

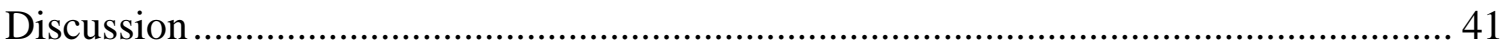

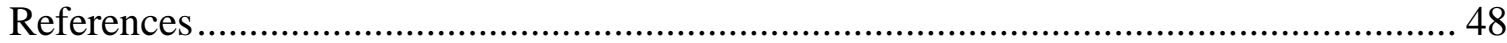




\section{List of Tables}

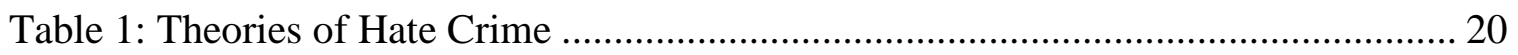

Table 2: Negative Binomial Regression: Anti-LGB Crimes After Marriage Equality

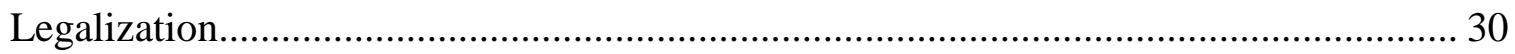

Table 3: Negative Binomial Regression: Anti-LGB Crimes After Marriage Ban............ 31

Table 4: Negative Binomial Regression: Anti-LGB Crimes Before Marriage Ban ......... 33

Table 5: Characteristics of Anti-LGB Offenses 7 Days After Marriage Ban.................. 39 


\section{List of Figures}

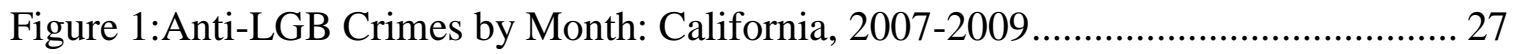

Figure 2: Anti-LGB Weekly Proportion of Hate Crimes: California, 2007-2009 ........... 28

Figure 3: Anti-LGB Crimes by Week: California, 2007-2009 .................................... 28

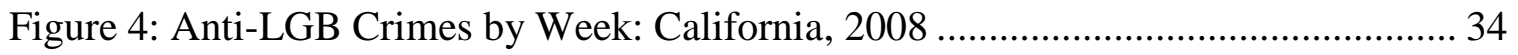

Figure 5: November Anti-LGB Crimes by Day: California, 2007-2009 ........................ 35 
Anti-LGB Hate Crimes: Political Threat or Political Legitimization?

\section{Introduction}

In the ten days following the 2016 presidential election, the Southern Poverty Law Center received reports of 867 hate incidents via user submission and media accounts (Miller \& Werner-Winslow, 2016), 227 of which occurred the day after the election (Hatewatch, 2017). Some of the perpetrators of these incidents directly implicated the election result in their motivation, seeking to inform their victims that they would no longer be afforded the relative safety they had enjoyed under previous administrations. For example, a trans couple received a note under their door reading, “you aren't protected anymore queers" (Hatewatch, 2017) and a 75-year-old man was beaten and told "my new president says we can kill all you faggots now" (Miller \& Werner-Winslow, 2016). Although SPLC had no similar data collection procedure in place prior to the election, these numbers and examples suggest that the election of a presidential candidate who relied heavily on biased speech against several vulnerable minority groups during his campaign (Crandall, Miller, \& White, 2018) may have had a significant impact on hate activity across the United States.

While activists have often argued that the legitimization of biased attitudes and stereotypes by political leaders foments violence against minority groups, much of the criminological research has focused more on "threat" hypotheses that view hate crime as a retaliatory response to perceived gains or encroachment of targeted groups. This thesis will assess theories of hate crime and gaps in the literature, with an additional focus on 
anti-LGB (anti-lesbian, gay, bisexual) crimes through the lenses of threat as well as bias legitimization. The study will test the effects of threat and legitimization of bias on antiLGB crime by analyzing data in relation to two different political events in California from the year 2008. In May 2008, the California Supreme Court ruled that a ban on marriage equality was unconstitutional, prompting the passage of a constitutional amendment banning same-sex marriage (Proposition 8) in November of the same year. The political threat hypothesis predicts that anti-LGB crimes will increase after the marriage decision, while the legitimization hypothesis predicts that more incidents will occur immediately following the passage of the marriage ban. The data will also allow for analysis of a related hypothesis that public visibility (e.g. high media coverage) of a contentious issue increases hate crime rates (Koopmans \& Olzak, 2004). This theory predicts that anti-LGB crimes will increase during the period leading up to the amendment vote, which was characterized by a controversial media campaign (Tasithoughts, 2009).

\section{Literature Review}

Criminological research into hate crime has most often followed a path carved by theories of racism and conflict perspectives of the criminal justice system, which view the system as catering to those in power and responding to "threats" posed by marginalized groups. Hate crime researchers who test threat hypotheses view hate crime less as a specific type of crime and more as a different type of social control that "defends" against 
perceived threats from outgroups. The first part of the literature review addresses research into various types of threat.

Opposing this view to some extent is the commonly held belief that legitimizations of bias from authority figures or other institutions, rather than the threat of improved status of outgroup members, encourages hate crime. Despite the popularity of this view in non-academic settings, there is not at this time a well-defined body of research into the effect of bias-legitimizing forces on hate crime. However, although a consistent and well-defined theoretical framework for legitimization hypotheses is lacking, many empirical findings relate to this perspective. The second part of the review will address this evidence.

Finally, the review will address evidence related to visibility and hate crime. The idea that enhanced visibility of bias issues, or hate crimes themselves, increases hate crime is another popular belief (e.g. Hess, 2009) which is often synthesized into other theories as a mediating force.

\section{Threat Hypotheses}

Many theories of hate crime can be subsumed under the umbrella of threat hypotheses. Evolving out of theories of racism and intergroup conflict (Blalock, 1967; Bobo, 1988; Suttles, 1972), these theories see hate crime as a response to a perceived threat from the outgroup. Research in this vein has tended to define threat in terms of 1) economic competition from outgroup members in an environment of scarcity; 2) 
population percent of outgroup; and 3) political threat via gains in rights or representation for the outgroup. Theorists have interrelated these elements and refined their operationalization in various ways. Accordingly, this review will consider the research results by type of threat, rather than by individual theory, to avoid repetition due to overlap between theories.

Economic Threat. Early theories of racial threat (e.g. Blalock, 1967) implicated competition for economic resources as an important source of perceived outgroup threat. Thus, the increased presence of outgroup members would prompt hate crime in areas where resources are scarce. However, most of the research has not linked economic factors to hate crime, though results are mixed (Green, McFalls, \& Smith, 2001; Lyons, 2008). Neither average household income nor change in income had an effect on hate crime in an Australian city (Benier, Wickes, \& Higginson, 2016). Krueger and Pischke (1997) found that economic variables such as unemployment and wage levels had no effect on anti-foreigner crimes in Germany after location in East or West Germany was controlled. However, another study found that $64 \%$ of the difference in rates of rightwing violence between East and West Germany was explained by unemployment rates (Falk, Kuhn, \& Zweimüller, 2011). These results can perhaps be reconciled if unemployment represents a greater opportunity to commit crimes rather than a motivating factor.

Studying pre-Holocaust Romania and Bulgaria, Brustein and King (2004) found that worse economic conditions increased anti-Semitic violence only in Romania, where 
Jews held more political power and economic resources. The relationship was the opposite in Bulgaria, where Jews had lower socioeconomic statuses.

One study found that anti-white crime was more likely to occur in disadvantaged communities; however, the opposite was true for anti-black crimes, which were more likely to occur in homogenous, white, advantaged communities (Gladfelter, Lantz, \& Ruback, 2017). The authors suggest that interactions between social disorganization variables can predict variations in hate crime based on motivation type; however, this obscures the social factors that make hate crime against a dominant group a different phenomenon from hate crimes against marginalized groups. In fact, some theorists embed the power dynamics of offender and target groups into their definition of hate crime, excluding crimes against dominant groups (Green, McFalls, et al., 2001).

Population-related Threat. Several theoretical perspectives involve population density of target groups in some way, with or without an accompanying economic threat. Racial threat is typically understood as a positive relationship between the outgroup population and biased crimes against that group (e.g. Bobo, 1988). Blalock (1967) combines increasing outgroup population with resource competition in his theory of group threat. Empirical findings often fail to support this classic iteration of racial threat theory (Green, McFalls, et al., 2001). For example, percent foreign population had no 
effect on ethnic violence in Germany (Koopmans \& Olzak, 2004 ${ }^{1}$ ), and hate crimes on college campuses actually decreased as black and Latino student populations increased (Stotzer \& Hossellman, 2012).

While Krueger and Pischke (1997) found a positive association with foreign population and anti-foreigner crimes in East Germany (no association was found in West Germany) it had a negative association with rates of anti-foreigner crimes per foreign resident; foreigners were less at risk when they made up a larger part of the population. It is important, therefore, that correlations caused by the availability of targets are distinguished from those that may be caused by perceived threat.

A variation on racial threat, the defended communities perspective (Suttles, 1972), predicts that hate crimes occur in areas with sudden influxes of targeted groups, functioning as a mechanism to defend the community identity. This model predicts that hate crimes happen where previously homogenous communities are "threatened" by a sudden change in racial or outgroup demographics. Unlike theories of resource competition, the defended communities perspective defines the "threat" as an attack on non-material values, i.e. cultural identity, rather than the material values of classic racial threat (Green, Strolovitch, \& Wong, 1998; Lyons, 2008). Accordingly, higher hate crime rates should occur with higher ingroup rather than outgroup populations (Lyons, 2008),

\footnotetext{
1 The non-significant result is reported in footnote 11 , page 210 .
} 
where community attachment is stronger. Green, Strolovitch, and Wong (1998) operationalized defended communities as traditionally white communities that had recently experienced influxes of minorities. They found higher rates of hate crimes in such neighborhoods in New York, whereas economic factors did not affect hate crime rates. Similarly, Lyons (2008) found that percent white population increased anti-black crimes; anti-black incidents were more likely to occur in previously homogenous white neighborhoods that had recently experienced an increase in black population. This effect only occurred in those neighborhoods with high community attachment, however, further supporting the defended communities perspective (Lyons, 2008). Gladfelter and colleagues (2017) found that hate crimes against blacks are more likely in unstable but advantaged homogenous white communities, while hate crimes against whites are more likely in unstable and disadvantaged communities. Lynch (2008) sought support for the defended communities perspective by examining the predictive role of hate crime; cities with hate crimes had higher rates of segregation, suggesting the use of hate crime to keep outgroup members out.

While the foregoing relationships between outgroup population and hate crimes are characterized by a convex curvilinear equation, such that outgroups achieve safety after their population reaches the tipping point, Piatkowska (2016) found a concave curvilinear relationship between foreign born population and racial hate crimes. Piatkowska suggested that such a relationship means that targeted group members are safer from hate crimes when they make up a larger proportion of the population, until a 
tipping point is reached when offenders stop caring about consequences. Piatkowska, however, acknowledged that the concavity of the curve could also be caused by increases in areas with more recent influxes, an explanation that fits better with other research.

Research in population based threat has mostly neglected LGB motivated crimes, probably due to the lack of LGB population data; however, Green, Strolovitch, Wong, and Bailey (2001) attempted to measure the relationship between anti-gay crimes and lesbian/gay population density in New York City using proxy measures for lesbian/gay population, which included a measure of same-sex roommates over 30 years old, as well as names from marketing lists of organizations related to gay and lesbian interests and donor lists from lesbian and gay elected officials. While they did find a positive relationship between the proxy measures of population density of gay men and anti-gay crimes $^{2}$, it is not clear from their analysis whether this relationship is caused by the greater availability of targets or a greater sense of threat, since the rates of anti-gay crime were calculated per capita, and not per gay capita.

Political Threat. Threat is also conceived of in terms of political power, predicting that outgroup gains in civil rights and positions of authority will increase hate crime. This perspective views hate crime as a response to situations where legal recourse is not available for a perceived grievance against members of an outgroup (King \&

\footnotetext{
${ }^{2}$ The relationship between the lesbian population proxy and anti-lesbian crimes was not significant.
} 
Sutton, 2013). Like other threat hypotheses, empirical results are mixed. King and Sutton (2013) found that racial hate crimes increased in response to contentious interracial trials with an outgroup victory, such as the acquittal of officers charged with the Rodney King beating, as well as terrorist attacks attributed by the media to Arab or Muslim groups. Notably, the hypothesis was not supported for a court decision legalizing same sex marriage in Massachusetts, which had no effect on anti-LGB crime (King \& Sutton, 2013).

In pre-Holocaust Romania, increased support for leftist parties that were associated with Jews has been linked with anti-Semitism; however, votes for left parties did not predict anti-Semitic acts by year (Brustein \& King, 2004). Specific to anti-LGB bias, a study found that the presence of Gay-Straight Alliances in schools decreased inschool victimization of lesbian, gay, bisexual, transgender, and queer (LGBTQ+) students (Marx \& Kettrey, 2016). If the installation of a GSA is interpreted as a form of political threat, this does not support the threat hypotheses; however, other variables could lead to both the presence of GSAs and lower anti-LGBTQ+ bullying, such as more tolerant attitudes.

Some authors, studying the outbreak of ethnic violence in 1990s Europe, have investigated political threat via a theory of protest movements called political opportunity structures. This theory sees far right violence as a form of protest, making it unnecessary when extreme right parties are in power (Braun \& Koopmans, 2010). Braun and Koopmans (2014) found that political decisions limiting rights of immigrants in Germany 
decreased anti-immigrant crimes. In another study, the same researchers found that right and extreme right electoral victories decreased ethnic violence, (Braun \& Koopmans, 2010). However, the effect of political decision-making disappeared when bystander responses were taken into account, indicating that the political opportunity structures reached actors via the responses of bystanders (Braun \& Koopmans, 2014). These bystander responses, unlike the political decision-making, showed approval of perpetrators' biases, complicating the relationship between legal victories for outgroups and violence against those groups.

Barbara Perry $(2001,2003)$ sees hate crime as a natural extension of legal forms of discrimination, including institutionalized discrimination, such as the disparities in the U.S. criminal justice system. Hate crimes punish those who "do difference" incorrectly; for example, gay men who are visible in public may be "taught a lesson" for violating societally accepted gender norms. This view to some extent underlies nearly all hate crime research; however, Perry focuses more on the responsibility of biased power structures in defining the "threat" presented by the outgroup, whereas many of the empirical studies reviewed have focused on this threat as the proximate cause of some hate crimes. While this is still a threat theory, it may prove more useful with respect to practical implications to focus more on the societal roots of biased responses to perceived threats.

Walter (2011) proposes that hate crime may be found at the intersection of socioeconomic strain and Perry's formulation of 'doing difference' based on cultural 
stereotypes. This theory sees outgroup members who are marginalized in society as a safe target to discharge the strain of shame from an offender's low socioeconomic status. Suitable targets are therefore defined by cultural stereotypes marginalizing outgroups (Walters, 2011). This theory provides a bridge between the threat of scarce resources and the potentially harmful effects of forces that legitimize bias. Like Perry's, this perspective is more comprehensive and perhaps more helpful than focusing primarily on the potentially negative effects of attempts to improve the position of marginalized groups.

\section{Legitimization Hypotheses}

Like Perry's $(2001,2003)$ work, criminological research on LGBT specific hate crime has focused more on the role of forces that legitimize bias against outgroups (e.g. Herek \& Berrill, 1992). While this area of the field has fewer quantitative studies than the threat approaches, there are several examples, mainly outside the U.S., as well as results from studies of related phenomena and results from studies of other theoretical perspectives. For example, one study showed a positive relationship between number of hate groups and far right fatal violence at the county level (Adamczyk, Gruenewald, Chermak, \& Freilich, 2014). Evidence that schools with Gay-Straight Alliances have lower rates of LGBTQ+ related victimization (Marx \& Kettrey, 2016) ${ }^{3}$ suggests that the inverse may also be true; if the legitimization of equity for outgroup members lowers

\footnotetext{
${ }^{3}$ As previously noted, this result may be a spurious correlation cause by more tolerant attitudes in schools that have GSAs.
} 
their risk of victimization, legitimization of biases against them may increase their risk. Evidence that hate crimes are more likely to involve multiple offenders and occur in public (Green, McFalls, et al., 2001) may point to a need for legitimization on the part of the bias-motivated offender.

The power differential hypothesis predicts that hate crimes are more likely in areas with lower outgroup populations because offenders are less likely to fear consequences in these areas (LeVine \& Campbell, 1972). The power differential hypothesis can be seen as somewhat opposite the threat hypotheses in that it emphasizes the need for empowerment or emboldening of offenders, which is not possible in areas with larger presence of outgroup members. This hypothesis has some empirical support; campuses with higher proportions of black and Latino students have fewer racial hate crimes, which is notable given that a higher population also provides a larger number of targets (Stotzer \& Hossellman, 2012). Similarly, although Disha, Cavendish, and King (2011) found that hate crimes against Arabs/Muslims were higher in US counties with a higher percent Arab population as well as those with a higher percent Muslim population, when anti-Arab crimes were expressed as a rate of percent Arab population (thereby controlling for the greater availability of targets) percent Arab population was negatively associated with rates of anti-Arab crimes. They further found that a large majority group population combined with small outgroup population increased hate victimization risk.

Moving beyond population measurement into more explicit measures of legitimization, a study in India compared attitudes toward stigmatized caste (SC) 
members in villages where electoral quotas for SC political representation (known as reservation) were instituted, to villages without reservation (Chauchard, 2014). The findings revealed that while villagers held the same stereotypes of SC members regardless of their political representation, villagers under reservation exhibited more accepting social and (perceived) legal norms. More relevant to the current study, reservation villagers were also much less likely to indicate that they would verbally abuse or threaten SC members who violated traditional behavioral expectations (Chauchard, 2014). Though it did not specifically address hate crimes, and measured the effects of legitimizing equality of an outgroup rather than legitimizing bias against them, this study demonstrated that improving the political position of outgroup members may dissuade biased individuals from acting on their biases, rather than motivating them to retaliate extra-legally via hate crime, as a threat hypothesis would predict.

Levin and McDevitt (2002) analyzed reports of hate offenses to create a four-part typology of hate offenders comprised of thrill, defensive, retaliatory, and mission offenders. The most common type, the thrill offender (66\%), commits hate crimes as a form of thrill-seeking. Rather than having a "pure" bias motivation, these offenders use the victim's status as a justification for their actions. According to the authors, this type of offender commonly targets gay victims due to the easy recourse to societal norms to justify their actions, as well as the expectation that consequences will be less likely or less severe. This view therefore depends heavily on the aforementioned assumption that hate crime lies on the end of a spectrum of socially accepted biases against the outgroup, 
and that this spectrum includes institutionalized discrimination (Levin \& McDevitt, 2002; Perry, 2001, 2003). Levin and McDevitt (2002) refer to the pervasive atmosphere of stereotyping and prejudice against outgroups as a "culture of hate" to which thrill offenders respond by selecting targets that society has defined as less than human. Gay men are suitable targets because they fear reporting anti-gay crimes due to potential revictimization by law enforcement, and because punishment of anti-gay crimes is likely to be less severe or non-existent.

The second most common type of hate offender is the defensive offender (25\%), who acts to protect his own "turf" (Levin \& McDevitt, 2002). This offender stays in his neighborhood rather than traveling to "gayborhoods" to hunt victims. This typology fits well with the defended communities perspective as well as other forms of threat response; however, it is worth noting that the proportion of offenders who are defensive is less than half the proportion of thrill offenders, who are motivated more by forces legitimizing bias.

Like Perry, Levin and McDevitt (2002) weave both threat and legitimization into their thesis; hate offenders have learned the same cultural stereotypes and biases as nonoffenders but they are distinct from non-offenders in their lack of power in society. They blame this lack of power on outgroup members who have been positioned by cultural conventions as worthy of blame. In this way, they are able to explain increases in hate crime caused by legitimizing bias as well as increases caused by retaliation against increased outgroup status. For example, Ann Coulter's suggestion to invade Arab 
countries, kill their leaders, and convert them to Christianity was followed by an increase in anti-Arab crimes; while an upswing in anti-gay crimes in Massachusetts in 1992 was thought to be due to gay people occupying positions of power and becoming more visible.

In a study examining the differences between youth who did and did not engage in anti-gay behaviors, Franklin (2000) found that while anti-gay ideology predicted 15\% of variance, peer pressure accounted for $35 \%$. Based on these results, she posited two types of anti-gay offenders: the ideological offender, who enforces anti-gay social norms of masculinity, and the follower, who goes along with the peer group. Interestingly, the study also found that $30 \%$ of non-offenders said they would harass or assault a gay person who flirted with them, "suggest[ing] a cultural permission to engage in violence based on homosexual innuendo" (Franklin, 2000, p. 354). This suggestion implicates a threat associated with gay people being visible, as well as the influence of societal legitimizations of bias.

Although their study found that strength of pro-immigrant agenda increased xenophobic violence, while stronger far right parties decreased it, Braun and Koopmans's (2014) framework pointed to a more immediate form of legitimizing bias via bystander response to anti-immigrant riots in Germany. When attacks on immigrants received positive responses from bystanders, such as cheering for the rioters or impeding police responses, far right violence increased in nearby areas; the hazard rate was five times higher in counties (Kreise) where bystanders responded positively to attacks in the 
previous month. While Braun and Koopmans (2014) emphasize that the local response was a necessary intermediary for the offenders, who were unlikely to watch the news, the theory still presents a legitimization of bias leading to more biased violence. In fact, that the rioters were "more attuned" to their immediate settings suggests that the political threat of pro-immigrant policy may not be affecting them as much as the legitimization from their immediate social environment, especially considering that the effect of the threat was completely mediated by bystander response. Furthermore, these results underline the importance of the character of political participation in each setting. The current study involves a court decision, with little public participation and a decision made by popular vote. The effects of vote on Prop. 8 may be more similar to effects of bystander responses, since it represented the approval of biases by peers.

Other European scholars have been more explicit in indicting legitimizing forces in hate crime causation. Von Trotha (1995) viewed the rash of ethnic violence in Germany in the early 1990's as a result of the process of political legitimization of the radical right, characterized by a neutralization of the history of Nazism, the creation of a "vocabulary of stigmatization and discrimination" (p. 39) used by politicians, media and citizens, the institutionalization of discrimination through restrictions on civil rights, and the trivialization of ethnic violence by the criminal justice system. Germany is unique among European nations, von Trotha argues, due to the "basic story" of its political culture, namely, the history of Nazism. The differential hate offending in Germany during the period is explained by the political culture's attempts to neutralize the 
shameful past through techniques such as "putting the past behind us," uniting the perpetrator and victim, and distancing "real" Germans from the actions of the Holocaust (Trotha, 1995).

Koopmans and Olzak (2004) empirically tested a hypothesis of political legitimization as well as competing theories of economic deprivation and ethnic competition. Ethnic competition, measured by immigration change, unemployment, and the interaction between immigration and unemployment had no significant effect on ethnic violence, aside from the effect of immigration change alone. The economic deprivation measures of domestic product and unemployment had no effect. The authors' "discursive opportunities" theory, on the other hand, received more support. This model predicts that political leaders affect right wing violence via discursive opportunities, marked by "public visibility, resonance, and legitimacy" (p. 199). Visibility means successful competition to be in the media. Resonance increases visibility via reactions from prominent public figures, which makes the message more newsworthy. Legitimacy is a measure of how many of the reactions by third parties are supportive of the biased message. Legitimacy, visibility, and resonance all increased ethnic violence.

\section{Visibility, Imitation, and Diffusion}

Public visibility via media coverage interacts with all of these frameworks in several ways, as can be seen from the foregoing review. Media coverage of political events that legitimize equality or bias is a prerequisite for any effect of these events on 
hate crime activity; however, increased visibility in the media may exert its own influence or mediate the influence of other causal factors. Testing a threat hypothesis related to political rhetoric, Hopkins (2010) found that anti-immigrant opinions increased in places with demographic changes to a greater extent when immigration had more media attention; however, greater salience in the media had the opposite effect in areas with no demographic change. Von Trotha's (1995) hypothesis views the media as an important source of the political legitimization of the far right, inciting right wing violence against immigrants. Likewise, Koopmans and Olzak's (2004) discursive opportunities theory relies on "visibility" as well as "consonance," the amount of biasaffirming statements found in the media, to explain the role of bias legitimization in ethnic violence, both of which had an effect on rates of violence in the study.

Braun and Koopmans's (2014) study of the bystander effect on ethnic violence asserts that while the immediate bystander effect was the key to inciting more ethnic violence, the media plays a role in telling some of the bystanders what the salient issues are. They found no difference in the models when they included a "visibility measure," supporting their hypothesis that the media does not play the primary role in influencing such violence. Braun and Koopmans's 2010 study, however, viewed hate crimes as a result of diffusion and imitation via the media. They found an increase in hate crimes related to several measures of media diffusion: 1) hate crime headlines appearing on the front page; 2) severity of hate crimes in the media; 3 ) the presence of a photo in media accounts; and 4) hate incidents mentioned in more than one source. The number of 
negative statements about immigrants per week increased the hazard ratio by $5 \%$ for each statement (Braun \& Koopmans, 2010).

Brustein and King's (2004) comparison of Bulgaria and Romania, discussed above, also addressed media coverage. While Romania had many more anti-Semitic acts (431) than Bulgaria (46) from 1899 to 1939 , content analysis revealed less media coverage related to Jews (88 versus 156 mentions) in Romania. Coverage of antiSemitism was somewhat more common in Romania, but the most notable difference in the content of coverage was attitude toward Jews. Forty-one percent of articles in Romania had unfavorable views on Jews, versus $6 \%$ in Bulgaria (Brustein \& King, 2004). This evidence suggests that media coverage may contribute to hate crime rates through legitimization of bias rather than simply visibility.

Table 1 summarizes the factors related to threat as well as legitimization found in each of the theories, perspectives, or models reviewed above. This table visualizes the significant presence of bias-legitimizing forces in theories of hate crime; despite the tendency of the research to focus on testing threat hypotheses, all but one of the reviewed theories contains or implies some element of bias-legitimization. As discussed above, threat hypotheses start with the assumption that bias exists both in the individual and society to some extent; however, this aspect of hate crime causation has been neglected by empirical research as well as theoretical explorations. 


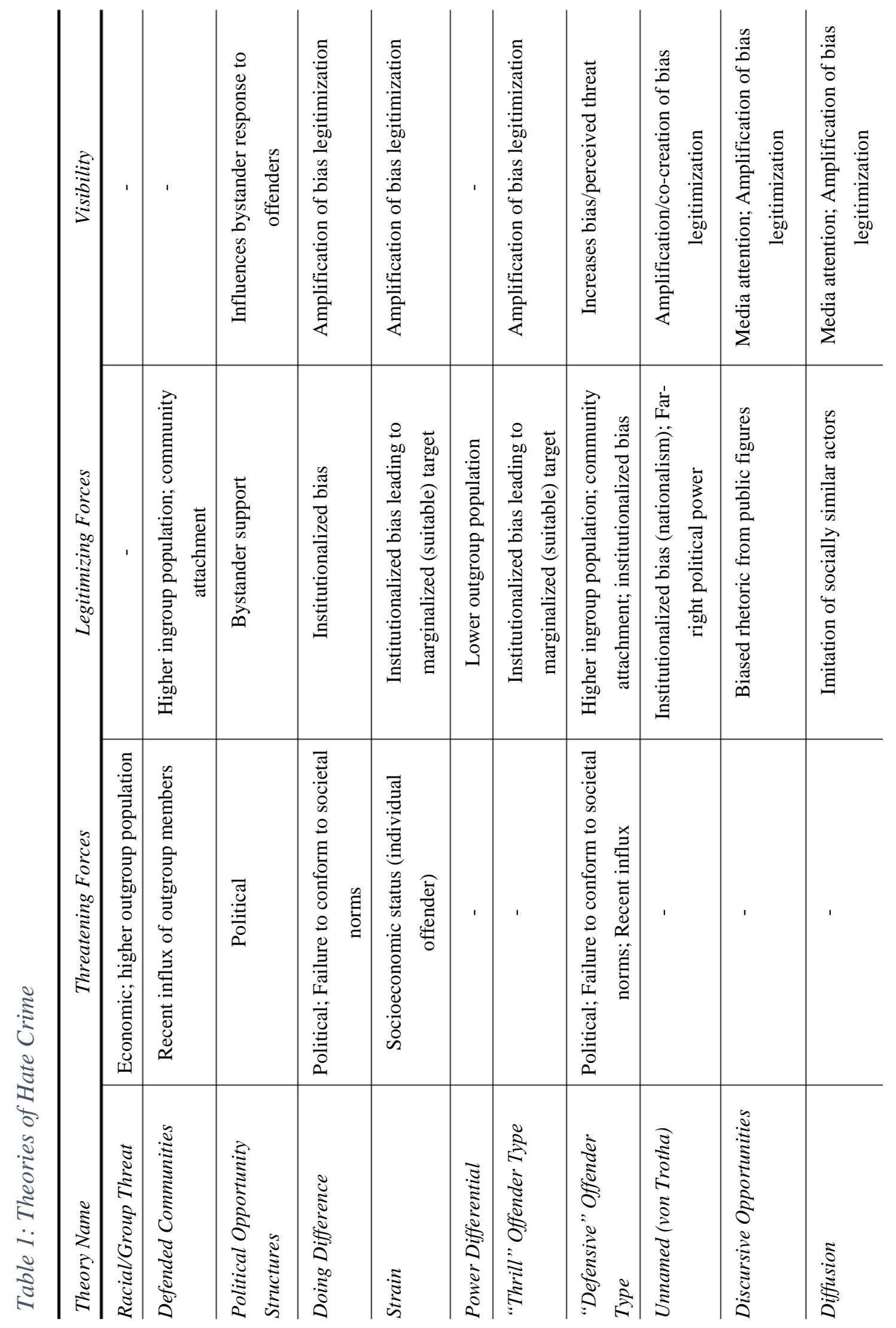




\section{Hypotheses}

Based on the foregoing review, this study will test three hypotheses related to political events and anti-LGB crimes. If retaliation/threat is important to hate crime causation, hate crimes will increase after the court decision to legalize marriage equality, as this decision to expand civil rights for the outgroup represents a perceived political threat, motivating offenders to "defend" against the threat using extralegal measures. If legitimization of bias is important, anti-LGB crimes will increase after the Prop. 8 vote, as a codified ban on marriage equality represents a legitimization of bias against samesex couples, which according to this perspective, would mobilize offenders with biases to act on them, knowing they have some level of approval. Finally, if visibility is more important, hate crimes will increase leading up to the vote, during times when ads were prevalent, as well as around the two events, due to the increased salience of issues related to outgroup bias. The following three hypotheses will therefore be tested:

1) Threat Hypothesis: Variables representing 7, 14, and 30 days after the decision to legalize will have a significant, positive effect on anti-LGB crime counts.

2) Legitimization Hypothesis: Variables representing 7, 14, and 30 days after Prop. 8 will have a significant, positive effect on anti-LGB crime counts.

3) Visibility Hypothesis: Variables representing 30, 14, and 7 days prior to the Prop. 8 vote will have a positive effect on anti-LGB crime counts. 


\section{Methods}

One of the greatest obstacles to studying correlates of hate crime in the United States is the lack of reliable data. According to the National Crime Victimization Survey (NCVS), in 2012, $60 \%$ of hate crimes were not reported to police. Of those crimes reported, only six percent were confirmed by police as bias-motivated (Meuchel Wilson, 2014). Members of the LGBT community as well as victims of other bias types underreport bias crimes due to beliefs that police share the biases of their perpetrators (Briones-Robinson, Powers, \& Socia, 2016). The hate crime data from the UCR represent only those crimes 1 ) reported to the police, 2) identified by the police as hate crimes, and 3) reported to the FBI by the agency and state. UCR reporting of hate crimes varies widely by state; for example, in Georgia six agencies participated in the 2008 hate crime report, covering a population of 554,193 , for a total of nine incidents, compared to California's 730 reporting agencies, which covered a population of 37 million $(1,381$ incidents) (FBI, 2009). In 2008, the National Crime Victimization Survey recorded 155,090 hate crime victimizations compared to 9,610 recorded by the UCR (Meuchel Wilson, 2014). Studying rates within a single jurisdiction eliminates the problems of comparison between samples articulated using different reporting procedures; however, the rate at which incidents are reported in a single jurisdiction must remain constant over time (Green, McFalls, et al., 2001). In order to alleviate these issues and control for any socioeconomic or other contextual factors, this study targets two events from the same year in the same jurisdiction to examine their effects on anti-LGB hate crimes. 


\section{Antecedent Events}

On May 15, 2008, the California Supreme Court ruled that a law barring same-sex couples from marriage was unconstitutional, legalizing marriage equality in the state. Around the same time, Proposition 8, an amendment to the state constitution that would ban marriage equality, was added to the ballot, and in November that year, after a contentious political and advertising campaign (Badash, 2014), it passed, rendering marriage equality illegal again. These events constitute 1) a legitimization of gay rights, a form of perceived outgroup threat according to the threat frameworks, followed by 2) a legitimization of bias, in a publicly visible campaign that involved anti-gay rhetoric (Tasithoughts, 2009). The two events differ in the sense that the California Supreme Court marriage decision did not have a campaign leading up to it, however, media coverage made it publicly visible (e.g. Nichols, 2008).

\section{Visibility}

An extensive campaign led up to the vote on Proposition 8, the most expensive social issue campaign in U.S. history up to that point (Sayre, Bode, Shah, Wilcox, \& Shah, 2010). Newspaper coverage started ramping up in September, and dropped off immediately following the vote, with the highest concentration of coverage in the month leading up to the vote. An analysis of media coverage noted that YouTube videos played a role as well, perhaps as a platform for those who felt "dissociation" from the mainstream media. The videos, most of which opposed Prop. 8, ramped up immediately 
prior to the vote and then increased for a very short period following the vote (Sayre et al., 2010).

\section{Measures}

Dependent Variable. The dependent variable, anti-LGB hate crime, includes those incidents recorded in the FBI's Uniform Crime Report. While the UCR represents a vast understatement of hate crime and is not a reliable comparison between jurisdictions, the state of California has consistently submitted reports from a large number of agencies. As the first state to enact hate crime legislation, in 1978 (Lyons, 2008), California's hate crime reporting procedures are more reliable than many states and offer a relatively large number of incidents for testing. Furthermore, any idiosyncrasies in reporting specific to the state or the year will not affect the analysis because both events occurred in the same reporting year. The other primary measure of hate crime in the U.S., the NCVS, is not suitable for this analysis as it does not identify the specific location or date of incidents. This analysis includes counts of hate crimes for each day in a three-year period, from 2007 to 2009 , for a total $\mathrm{N}$ of 1,095 days.

Independent Variables. The independent variables of interest include dummy variables indicating dates in the following categories: 1) Dates falling within 7, 14, and 30 days after the decision to legalize same sex marriage will constitute the effect of political threat on anti-LGB counts; 2) dates 30,14, and 7 days prior to the Prop. 8 vote will measure the effect of visibility; and 3) dates within 7, 14, and 30 days after the vote 
will measure the effect of political legitimization of bias. For example, all seven days following the Prop. 8 vote were coded 1, while all other days from 2007 to 2009 were coded 0 , to assess whether the daily number of LGB hate crimes in California increased during these seven days compared to all other days, controlling for other important factors.

Control Variables. Following King and Sutton (2013), the analysis will control for several variables that impact hate crime rates. Like other crimes, hate crimes happen more in the summer and on weekends. Dummy variables for summer, defined as dates between June 1 and August 31, and days of the week (Sunday =0) are included in all models. Any effect caused by the specific year is controlled via dummy variables for each year. Variations in hate crimes in general are controlled by including counts for all other types of hate crime (bias motivations other than LGB), and the effect of ongoing time (the correlation of hate crimes with future hate crimes) is controlled by numbering each day consecutively and including it as a variable in the model.

\section{Analysis}

Due to their low frequency, the hate crime counts in this dataset do not follow a normal distribution as required for linear regression techniques. Poisson regression is often used to analyze the effect of predictor variables on counts of rare events. However, one of the assumptions of the Poisson distribution is that the mean and variance are the same. Analysis indicated that the variance of the dependent variable was higher than its 
mean, indicating overdispersion (Green \& Spry, 2014). For this reason, negative binomial regression was used.

\section{Results}

Counts of anti-LGB crimes during the 1,095-day period ranged from zero to four per day, with a mean of 0.70 and variance of 0.724 . Descriptive and statistical analyses supported the bias legitimization hypothesis, but did not support the threat or visibility hypotheses.

\section{Descriptive Analysis}

Preliminary graphic analyses of the data show rather striking support for the legitimization hypothesis. Comparing monthly counts of anti-LGB crimes, Figure 1 reveals a three-year high of $43^{4}$ in November 2008, the only count outside two standard deviations (6.39) of the three-year monthly mean of 20.86 LGB hate crimes. Since the vote on Prop. 8 happened on November 4, 2008, this spike primarily represents the weeks following the ban on marriage equality.

\footnotetext{
${ }^{4}$ Monthly counts were adjusted to represent 30 -day periods.
} 


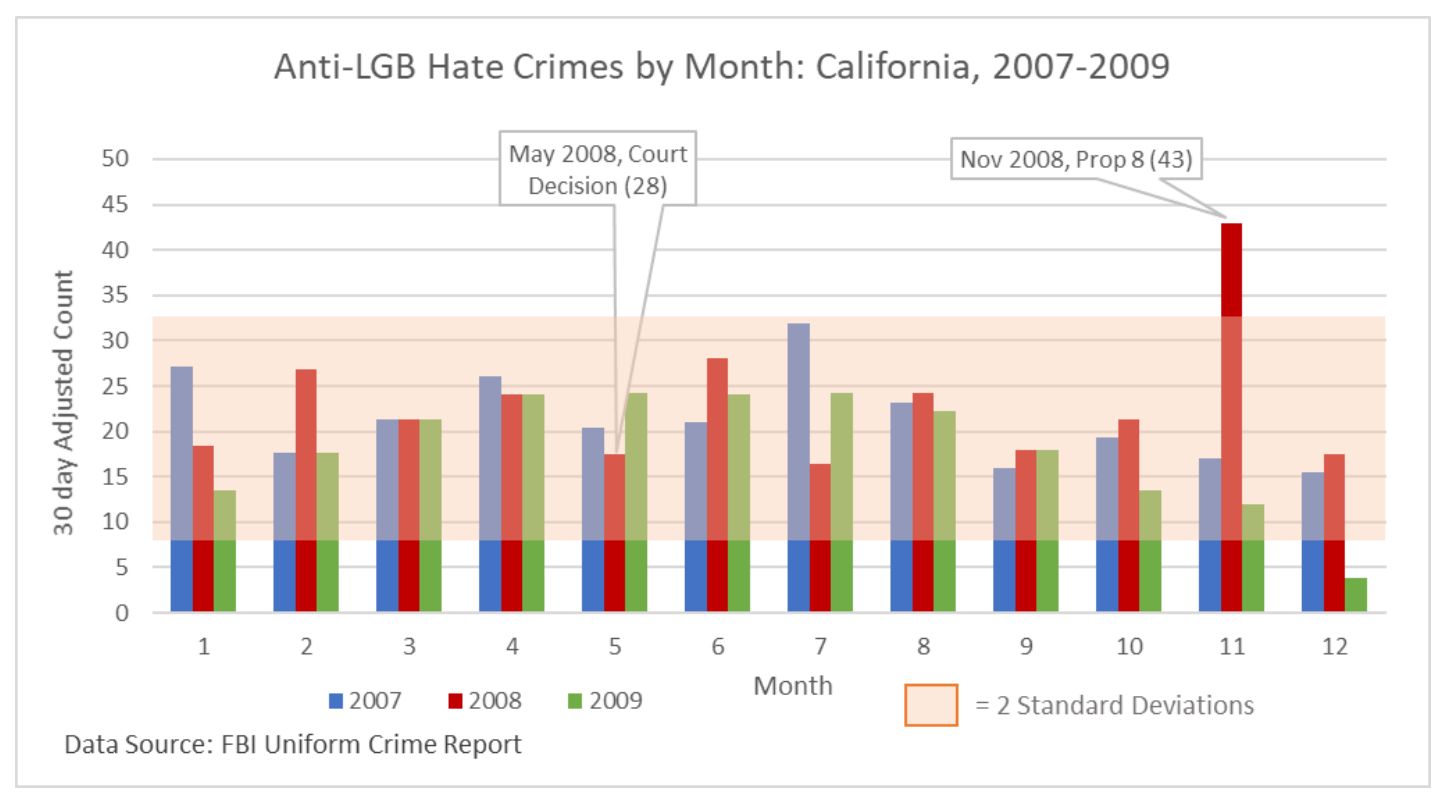

Figure 1:Anti-LGB Crimes by Month: California, 2007-2009

Zooming in on weekly counts, the spike in anti-LGB crimes becomes even more noticeable. While the counts displayed in Figure 3 represent weeks beginning on Sunday, since the Prop. 8 vote happened on a Tuesday, the weekly count primarily represents the days following the marriage ban. The week of the vote saw a three-year high of 18 antiLGB crimes, well outside two standard deviations (2.53) of the three-year mean, 4.80 . 

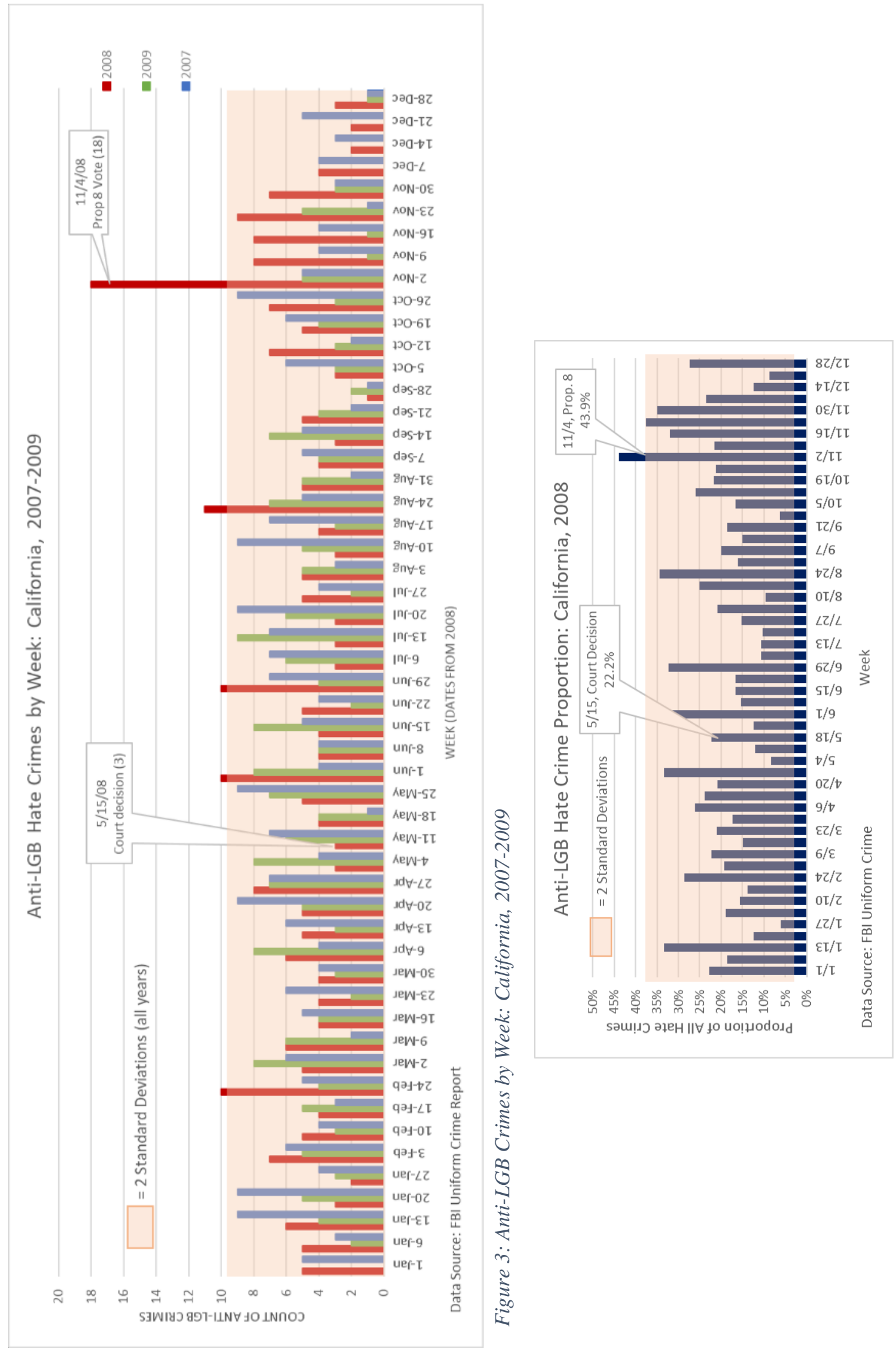

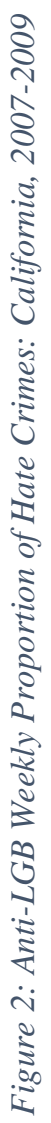


Viewing anti-LGB crimes as a proportion of all hate crimes reveals that the increase is not explained by an increase in hate crimes overall; the monthly (not pictured) and weekly (Figure 2) proportion of hate crimes with anti-LGB bias were also outside two standard deviations of the mean proportions. In contrast, the days and weeks following the decision to legalize marriage equality showed no difference in anti-LGB crimes. Further, there is no change in anti-LGB counts preceding the Prop. 8 vote, during the media campaign.

\section{Statistical Analysis}

Statistical analyses of the effects of the antecedent events appear in Tables 2 through 4. All models had significant likelihood ratio chi square tests, showing good fit and allowing interpretation of parameter estimates of the negative binomial regression. Table 2 shows results of models testing the threat hypothesis. The coefficients for the 7 , 14, and 30 days after legalization by the California Supreme Court were all not significant. Hence, the first hypothesis was not supported; the legalization of marriage equality did not show a significant effect on anti-LGB hate crime counts in the analysis.

Table 3 summarizes results of the models testing the legitimization hypothesis. Coefficients for 7, 14 and 30 days after the Prop. 8 vote were significant and positive. Thus, the second hypothesis was supported; the popular vote to ban marriage equality was followed by a statistically significant increase in anti-LGB hate crimes. 
Table 2: Negative Binomial Regression: Anti-LGB Crimes After Marriage Equality Legalization

\begin{tabular}{|c|c|c|c|c|c|c|}
\hline & \multicolumn{2}{|c|}{ Model 1} & \multicolumn{2}{|c|}{ Model 2} & \multicolumn{2}{|c|}{ Model 3} \\
\hline & $b$ & $S E$ & $b$ & $S E$ & $B$ & $S E$ \\
\hline Intercept & -.078 & .1854 & -.078 & .1854 & -.082 & .1854 \\
\hline Saturday $^{\mathrm{a}}$ & $-.349 *$ & .1699 & $-.348 *$ & .1699 & $-.351 *$ & .1699 \\
\hline Friday & $-.335 *$ & .1697 & $-.333 *$ & .1698 & $-.335^{*}$ & .1697 \\
\hline Thursday & $-.431 *$ & .1729 & $-.431 *$ & .1729 & $-.432 *$ & .1728 \\
\hline Wednesday & $-.450 * *$ & .1742 & $-.450 * *$ & .1742 & $-.450 * *$ & .1742 \\
\hline Tuesday & $-.525 * *$ & .1755 & $-.523 * *$ & .1755 & $-.525 * *$ & .1755 \\
\hline Monday & $-.349 *$ & .1699 & $-.349 *$ & .1699 & $-.351 *$ & .1699 \\
\hline Summer $^{b}$ & .178 & .1084 & .176 & .1085 & .181 & .1089 \\
\hline Year $=2009^{c}$ & .395 & .3587 & .398 & .3588 & .388 & .3595 \\
\hline Year $=2008$ & .355 & .2092 & .361 & .2097 & .344 & .2120 \\
\hline Time & -.001 & .0005 & -.001 & .0005 & -.001 & .0005 \\
\hline $\begin{array}{l}\text { All other hate crime } \\
\text { count }\end{array}$ & .046 & .0260 & .046 & .0260 & .047 & .0260 \\
\hline \multirow[t]{2}{*}{ Post Legalization } & \multicolumn{2}{|c|}{+7 days } & \multicolumn{2}{|c|}{+14 days } & \multicolumn{2}{|c|}{ + 30 days } \\
\hline & -.524 & .6976 & -.389 & .4727 & -.010 & .2881 \\
\hline Log Likelihood & \multicolumn{2}{|c|}{-1243.671} & \multicolumn{2}{|c|}{-1243.620} & \multicolumn{2}{|c|}{-1243.970} \\
\hline
\end{tabular}

$* p<.05 * * p<.01$

${ }^{\text {a }}$ Days of week are individually compared to Sunday

${ }^{\mathrm{b}}$ Summer days are from June 1 to August 31, compared to all other days of the year. Note ${ }^{\mathrm{c}}$ Years 2009 and 2008 are compared to 2007.

Note: all models also include a time variable representing each day of 2007 through 2009 
Table 3: Negative Binomial Regression: Anti-LGB Crimes After Marriage Ban

\begin{tabular}{|c|c|c|c|c|c|c|}
\hline & \multicolumn{2}{|c|}{ Model 1} & \multicolumn{2}{|c|}{ Model 2} & \multicolumn{2}{|c|}{ Model 3} \\
\hline & $b$ & $S E$ & $b$ & $S E$ & $b$ & $S E$ \\
\hline Intercept & -.018 & .1871 & -.022 & .1873 & -.002 & .1876 \\
\hline Saturday ${ }^{\mathrm{a}}$ & $-.352 *$ & .1702 & $-.352 *$ & .1701 & $-.367^{*}$ & .1704 \\
\hline Friday & $-.341 *$ & .1703 & $-.340^{*}$ & .1701 & $-.345^{*}$ & .1703 \\
\hline Thursday & $-.427 *$ & .1731 & $-.427 *$ & .1730 & $-.425^{*}$ & .1732 \\
\hline Wednesday & $-.452 *$ & .1744 & $-.453 * *$ & .1744 & $-.458^{*}$ & .1746 \\
\hline Tuesday & $-.541 * *$ & .1760 & $-.533 * *$ & .1758 & $-.538^{*}$ & .1760 \\
\hline Monday & $-.355^{*}$ & .1702 & $-.356^{*}$ & .1701 & $-.355^{*}$ & .1703 \\
\hline Summer $^{\mathrm{b}}$ & .211 & .1089 & .212 & .1092 & $.234 *$ & .1099 \\
\hline Year $=2009^{c}$ & .538 & .3637 & .547 & .3661 & .695 & .3750 \\
\hline Year $=2008$ & .380 & .2096 & .382 & .2098 & $.417 *$ & .2112 \\
\hline Time & -.001 & .0005 & -.001 & .0005 & $-.001 *$ & .0005 \\
\hline $\begin{array}{l}\text { All other hate crime } \\
\text { Count }\end{array}$ & .037 & .0264 & .039 & .0263 & .043 & .0262 \\
\hline \multirow[t]{2}{*}{ Post Marriage Ban } & \multicolumn{2}{|c|}{+7 days } & \multicolumn{2}{|c|}{ + 14 days } & \multicolumn{2}{|c|}{ + 30 days } \\
\hline & $1.258 * *$ & .4734 & $.847 *$ & .3683 & $.814 * *$ & .2746 \\
\hline Log Likelihood & \multicolumn{2}{|c|}{-1240.116} & \multicolumn{2}{|c|}{-1241.269} & \multicolumn{2}{|c|}{-1239.546} \\
\hline
\end{tabular}

$* p<.05 * * p<.01$

${ }^{a}$ Days of week are individually compared to Sunday

${ }^{\mathrm{b}}$ Summer days are from June 1 to August 31, compared to all other days of the year. Note ${ }^{\mathrm{c}}$ Years 2009 and 2008 are compared to 2007.

Note: all models also include a time variable representing each day of 2007 through 2009 
Table 4 shows results of the negative binomial regression on the periods 30,14 , and 7 days before Proposition 8, testing the visibility hypothesis. All three coefficients were not significant. Therefore, the third hypothesis was not supported; no effect on antiLGB crimes was observed during the period of media coverage before the Prop. 8 vote. While media coverage related to Prop. 8 and marriage equality continued after the vote and during the period of increased anti-LGB activity, the analysis did not find an independent effect on hate crimes, due to the lack of significance for the periods when any influence of visibility would be operating independent of the bias-legitimizing influence of the vote.

To explore the duration of the effect of the Prop. 8 vote found in the analysis, variables representing 45-day, 60-day, and 90-day periods after the marriage ban were tested using the same models. The 45-day period was significant $(b=.681, \mathrm{SE}=.2457, \mathrm{p}$ $<.01)$, as was the 60 -day period $(b=.487, \mathrm{SE} .2307, \mathrm{p}<.05)$. The 90 -day period was not significant. However, as seen in Figure 4, weekly counts of hate crimes against LGB persons returned to average or below average levels after about a month. The significant results for the 45 and 60-day periods are likely reflecting the strength of the effect from the earlier time periods. Still, the 30-day effect of the bias-legitimizing event in this case was more enduring than the brief spike and quick decay found by King and Sutton (2013) with respect to threat-inspired retaliatory hate crimes. 
Table 4: Negative Binomial Regression: Anti-LGB Crimes Before Marriage Ban

\begin{tabular}{|c|c|c|c|c|c|c|}
\hline & \multicolumn{2}{|c|}{ Model 1} & \multicolumn{2}{|c|}{ Model 2} & \multicolumn{2}{|c|}{ Model 3} \\
\hline & $B$ & $S E$ & $b$ & $S E$ & $b$ & $S E$ \\
\hline Intercept & -.066 & .1856 & -.064 & .1857 & -.067 & .1857 \\
\hline Saturday $^{\mathrm{a}}$ & $-.343 *$ & .1700 & $-.342 *$ & .1701 & $-.338^{*}$ & .1702 \\
\hline Friday & -.330 & .1699 & -.330 & .1699 & -.328 & .1699 \\
\hline Thursday & $-.432 *$ & .1730 & $-.429 *$ & .1730 & $-.424 *$ & .1730 \\
\hline Wednesday & $-.443 *$ & .1743 & $-.444 *$ & .1743 & $-.442 *$ & .1743 \\
\hline Tuesday & $-.521 * *$ & .1756 & $-.521 * *$ & .1756 & $-.515^{* *}$ & .1757 \\
\hline Monday & $-.358 *$ & .1701 & $-.355^{*}$ & .1701 & $-.351^{*}$ & .1700 \\
\hline Summer ${ }^{\mathrm{b}}$ & .195 & .1086 & .199 & .1089 & .201 & .1093 \\
\hline Year $=2009^{c}$ & .464 & .3617 & .479 & .3636 & .488 & .3670 \\
\hline Year $=2008$ & .358 & .2091 & .360 & .2092 & .360 & .2094 \\
\hline Time & -.001 & .0005 & -.001 & .0005 & -.001 & .0005 \\
\hline $\begin{array}{l}\text { All other hate crime } \\
\text { Count }\end{array}$ & .046 & .0260 & .046 & .0260 & .046 & .0260 \\
\hline \multirow[t]{2}{*}{ Pre-Marriage Ban } & \multicolumn{2}{|c|}{ - 7 days } & \multicolumn{2}{|c|}{ - 14 days } & \multicolumn{2}{|c|}{ - 30 days } \\
\hline & .869 & .4982 & .621 & .3787 & .383 & .2843 \\
\hline Log Likelihood & \multicolumn{2}{|c|}{-1242.400} & \multicolumn{2}{|c|}{-1242.621} & \multicolumn{2}{|c|}{-1243.066} \\
\hline
\end{tabular}

$* p<.05 * * p<.01$

${ }^{a}$ Days of week are individually compared to Sunday

${ }^{\mathrm{b}}$ Summer days are from June 1 to August 31, compared to all other days of the year. Note ${ }^{\mathrm{c}}$ Years 2009 and 2008 are compared to 2007.

Note: all models also include a time variable representing each day of 2007 through 2009 


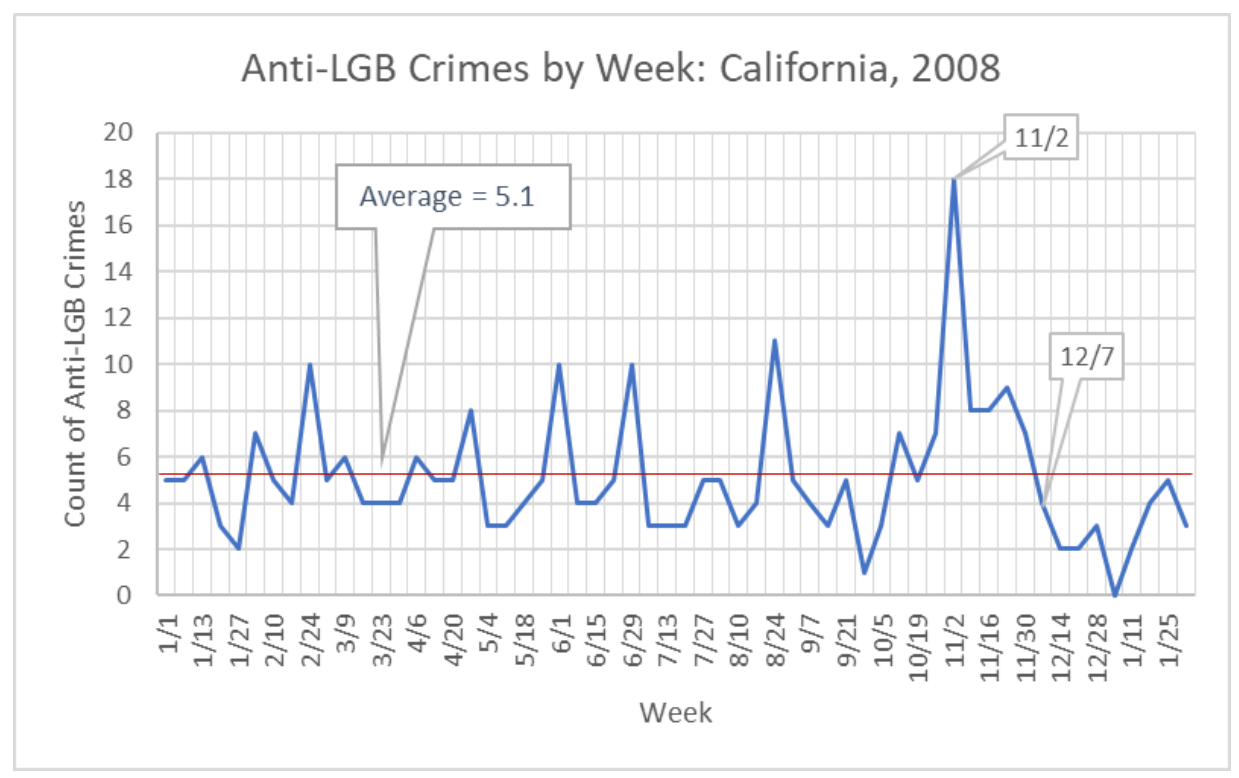

Figure 4: Anti-LGB Crimes by Week: California, 2008

\section{The First Seven Days}

In order to provide further illumination on the nature of the relationship between legitimization, threat, and hate crimes, a more in depth analysis of the anti-LGB incidents that occurred in the seven days following the Prop. 8 vote was conducted. Interestingly, examining the daily counts for just November reveals that a spike in anti-LGB crime appears to have started two days prior to the passage of Prop. 8. While these two days did not result in a statistically significant effect of the week prior to the vote, they are notable given the low average daily counts and their proximity to the vote. These days also coincide with the dramatic ramp up of YouTube videos a few days before the vote (Sayre et al., 2010). From a legitimization perspective, this pre-vote spike could also reflect the 
growing awareness that the vote was too close to call, after an expected victory for proponents of marriage equality (Audi, Scheck, \& Lawton, 2008); potential offenders would realize that there was more support for their biases than had been portrayed by the popular characterization of California as a liberal haven.

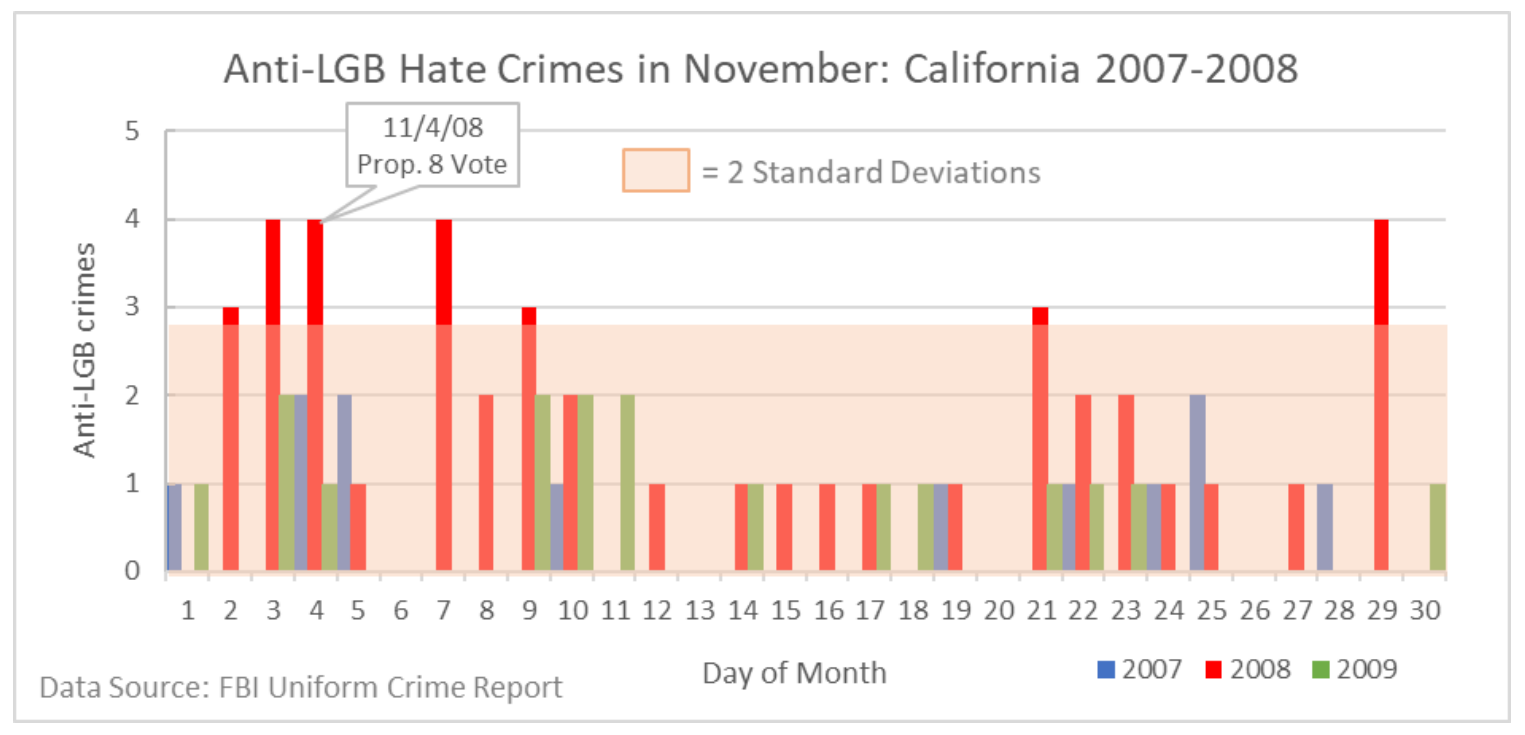

Figure 5: November Anti-LGB Crimes by Day: California, 2007-2009

The day of the vote on Proposition 8, four incidents with a total of five offenses targeted LGB status. One was vandalism against a business and three were assault or intimidation. One of the intimidation counts was accompanied by "other larceny." The day after the vote, a Wednesday, saw only one incident, vandalism against a business. Thursday was free of incidents, but nine more happened over the weekend: Friday and Saturday saw six incidents of assault, while Sunday had two incidents vandalism and one of intimidation. Two more incidents happened on Monday; one vandalism and one assault. 
Nine of the 12 offenses that occurred in the first five days after the ban (starting on the day of the vote, 11/4-11/8), were the person crimes of assault or intimidation. Counting incidents rather than offenses, 9 of 11 incidents included person crimes. The next two days saw two intimidation offenses and three vandalism offenses. These numbers are too small to make conclusions, but an exploratory look at the temporal clustering of offense types suggests the possibility that immediately after the antecedent event, responses may be more violent and personal than those coming later. In some ways this may support some connection to threat; anti-gay perpetrators who used physical force differed from others in that they exhibited a display of heterosexual identity (Franklin, 2000). Physical force can be interpreted as a sign of knee-jerk responses contrary to the consequence-fearing characteristic of an offender emboldened by legitimization of bias or peer approval. While this dichotomy may be a false or overstated one, even were it true, further temporal analysis provides another explanation: the more serious person crimes, i.e. assault, happened primarily during the weekend, which may indicate the involvement of alcohol. This explanation also accounts for the fact that the most immediate offenses (the day of the vote) were a mixture of person and property crimes.

The incidents follow the general crime pattern of occurring more on the weekends, when victims and offenders are more likely to converge. The exception is the four incidents that happened on the day of the vote. This appears to support the claim of King and Sutton (2013) that hate crimes spike immediately after antecedent events, followed by a drop-off. However, the statistical analyses showed increased anti-LGB 
incidents for a long time period up to 30 days, and the weekend incidents occurring during the first week suggest that any drop-off may not be absolute or permanent, and is not immune from the patterns of non-hate crimes.

Characteristics of the offenses are summarized in Table 4. None of the assaults happened at a residence; all were in public locations, such as on the street. This lends additional support to the idea that they may have been spontaneously prompted during social activities, and may have involved alcohol. Offenses that occurred at home were intimidation, vandalism, and other larceny. The vandalism offenses were for the most part committed against properties on "off” days; a bar was vandalized on the Tuesday of the vote, whereas an office building and residence were vandalized on the weekend, when they were more likely to be vacant. Despite the finding that hate crimes tend to be more violent than other crime (Messner, McHugh, \& Felson, 2004), these offenses do not show an excessive level of confrontation. For example, there were no aggravated assaults committed at a victim's home; as stated earlier, the assaults were primarily committed on the weekend when offenders may have been "aided," as it were, by alcohol.

Another factor that may relate to threat and legitimization is the macrogeographical location, in this case the city, where incidents occurred. Several of the incidents happened in some of the largest cities in California, including Los Angeles (4 incidents, including surrounding areas, such as West Hollywood), San Diego (2 including surrounding areas), San Jose (2), and Oakland (2). The smallest population area was Laguna Beach (24,035); however, its location in the Orange County Metropolitan 
Statistical Area (defined by the U.S. Census) makes it far from a rural setting. The offenses all occurred in suburban to urban settings, which at first glance supports a threat hypothesis, assuming the LGB population is more dense and visible in urban areas. However, due to the inconsistencies noted earlier with the UCR hate crime data, this likely reflects 1) underreporting in rural areas, where conservative social norms may convince victims that reporting will result in revictimization from authorities and little recourse; and 2) the greater availability of targets in areas with higher LGB populations. It may also reflect smaller agencies' failure to submit the voluntary hate crime report.

In a further attempt to explore the effect of political legitimization and threat, Table 5 lists the proportion of the county that voted yes on Prop. 8 (supporting the marriage equality ban) (Leip, n.d.), as well as the county proportion of the 2016 presidential vote won by Donald Trump (Guerra Gomez, n.d.). While the Trump vote proportion is not a perfect measure of the climate in the same counties eight years earlier, if political demographics can be assumed to be somewhat stable, it offers a more exact picture of the county's support of legitimized biases than votes for GOP candidates in general. Proportions above the statewide average of 0.52 for Prop. 8 and 0.38 for Trump are noted in the table. Eleven of the 16 incidents occurred in counties where $50 \%$ or more voted to ban marriage equality, with seven of those in counties where the percent who voted for the ban exceeded the statewide average. Only five of the 16 incidents occurred in counties where the proportion voting for Trump exceeded the state average; however, two additional incidents happened in a county that matched the average of 0.38 . Incidents 
occurring in pro-Prop 8 as well as pro-Trump counties are clustered at the beginning of the seven-day period. Since the vote to ban marriage equality was a popular one, these offenders may have been acting with the understanding that their social environments had exhibited some approval of anti-LGB bias.

Table 5: Characteristics of Anti-LGB Offenses 7 Days After Marriage Ban

\begin{tabular}{|c|c|c|c|c|c|}
\hline Offense & Population & $\begin{array}{l}\text { Yes on } \\
\text { Prop } 8\end{array}$ & $\begin{array}{l}\text { Trump } \\
\text { vote }\end{array}$ & Date & Location \\
\hline $\begin{array}{c}\text { Aggravated } \\
\text { Assault }\end{array}$ & $>500,000$ & .38 & 0.15 & $11 / 4 / 08$ & Street \\
\hline Intimidation & $200-500,000$ & $.67 *$ & $0.42 *$ & $11 / 4 / 08$ & $\begin{array}{c}\text { Gov/Public } \\
\text { Building }\end{array}$ \\
\hline Vandalism & $>500,000$ & $.54 *$ & 0.38 & $11 / 4 / 08$ & Bar \\
\hline $\begin{array}{l}\text { Intimidation/ } \\
\text { Other Larceny }\end{array}$ & $100-200,000$ & $.65^{*}$ & $0.45^{*}$ & $11 / 4 / 08$ & Home \\
\hline Vandalism & $<25,000^{*}$ & $.58 *$ & $0.43 *$ & $11 / 5 / 08$ & Street \\
\hline Simple Assault & $200-500,000$ & .38 & 0.15 & $11 / 7 / 08 * *$ & Parking Lot \\
\hline Simple Assault & $200-500,000$ & $.69 *$ & $0.46^{*}$ & $11 / 7 / 08 * *$ & Street \\
\hline Simple Assault & $>500,000$ & .50 & 0.23 & $11 / 7 / 08 * *$ & School \\
\hline Simple Assault & $50-100,000$ & $.53^{*}$ & $0.39 *$ & $11 / 7 / 08 * *$ & Restaurant \\
\hline $\begin{array}{l}\text { Aggravated } \\
\text { Assault }\end{array}$ & $>500,000$ & .50 & 0.23 & $11 / 8 / 08 * *$ & Street \\
\hline Simple Assault & $100-200,000$ & $.54 *$ & 0.38 & $11 / 8 / 08 * *$ & Gas Station \\
\hline Vandalism & $>500,000$ & .50 & 0.23 & $11 / 9 / 08^{* *}$ & Home \\
\hline Vandalism & $>500,000$ & .44 & 0.21 & $11 / 9 / 08^{* *}$ & Office \\
\hline Intimidation & $100-200,000$ & .34 & 0.23 & $11 / 9 / 08 * *$ & Home \\
\hline Vandalism & $>500,000$ & .50 & 0.23 & $11 / 10 / 08$ & School \\
\hline Intimidation & $>500,000$ & .44 & 0.21 & $11 / 10 / 08$ & Home \\
\hline
\end{tabular}


Notes: Population reflects the population of the largest city nearby (e.g., the population of LA was used for West Hollywood), in order to capture urban character *Proportion of county votes above state average ** Weekend day

\section{Limitations}

The limitations of the dataset used in this analysis were discussed at length above; however, the juxtaposition of two opposite events in the same jurisdiction and same reporting period gives the current study an advantage over many other uses of UCR data. Still, the confluence of two events in one year is not equivalent to the rigorous random control trial method, and causation is therefore difficult to infer. Furthermore, the narrowing of the study to anti-LGB crimes in California resulted in low base rates for the dependent variable. When the full 2016 UCR hate crime data become available, analyses on nationwide counts of all bias types by date will be possible to assess the effect of the election.

The results of this study do not test whether hate crimes are motivated by a combination of backlash against civil rights victories plus legitimization of biased views, as may be the case with current hate incidents since the 2016 presidential election. The analysis did not test whether the first event (legalization of same-sex marriage) was necessary in order for the second event to inspire to hate crimes; however, the findings suggest that when offenders perceive threat from an outgroup, they may not be empowered to act until some legitimization of their bias occurs, contrary to the predictions of many threat hypotheses. 
Furthermore, this location of this study in California keeps these results from being universally generalizable. It is possible and in fact probable that a state characterized as one of the most liberal in the United States would create a unique atmosphere for the response to a bias-legitimizing political victory. While no comparable combination of events and data were available for states considered conservative strongholds, it is not improbable that in a strongly conservative state, no increase in antiLGB crimes would accompany a constitutional ban on marriage equality. It may be that the unexpected victory of bias-legitimizing legislation in an environment thought to be hostile to such bias gave some offenders the motivation as well as security needed to commit anti-LGB crimes following the vote. This explanation implicates both threat and legitimization.

Finally, the 2008 election may have contained a confounding element; on the same day Prop. 8 passed, the U.S. elected its first black president. This event doesn't specifically concern LGB bias, as President Obama did not support marriage equality until after his election; however, it constitutes a significant political threat to biased members of the dominant group. That this threat had an effect on anti-LGB crimes, however, seems unlikely, as the analysis showed no increase in other hate crimes and the increase in anti-LGB crimes was significant after controlling for other hate crime counts.

\section{Discussion}

This study has attempted to answer to some extent the call of Green and Spry (2014) for more examination of the causal link between political institutions and hate 
crime. The following outlines the authors' perception of the missing link between bias legitimization and hate crime:

Third, the role of social norms lends itself to well-identified and substantively significant research. It is often argued that what people do in everyday life is heavily shaped by their perceptions about what others think. In particular, people are sensitive to standards—real or imaginedof socially acceptable attitudes and behaviors. This theoretical perspective implies that interventions that clarify or dramatize social norms may have a profound effect on the manner in which out-groups are regarded and treated, especially when it comes to extra-legal behaviors such as hate crime (Green \& Spry, 2014, p. 239).

The results of the current study support the notion that legitimizing forces do affect the treatment of outgroups, an idea popular audiences have understood for some time, likely due to their lived experience of such forces. In this study, this effect was visible in the short-term consequences of a single, regional event, but it was also visible for a month after the antecedent event legitimizing bias.

The enduring effect of the antecedent event contrasts with King and Sutton's (2013) dramatic decay. This could represent a difference between bias types within hate crimes, especially considering that King and Sutton's (2013) test of anti-LGB crimes was not significant; however, the persistent effects found in this analysis also mirror the 
prolonged drop off period that followed the immediate spike and drop-off of the hate response to the 2016 presidential election (Hatewatch, 2017). The prolonged period of decay is important to note, in order to avoid premature dismissals of increases as temporary (e.g. "The Apparent Rise in Hate-Crime," 2016). The difference in decay may, however, be related to the type of precipitating event; threat-related antecedents may show strong spikes and faster drop offs, while bias-legitimizing antecedents may have a more lingering effect. This distinction may also reflect the shock of an event such as a terrorist attack, as opposed to a long anticipated political decision.

\section{Future Research Recommendations}

It seems likely that perceived threat and legitimization of bias are inseparable at a theoretical level in the study of hate crime causation. However, the foregoing study has demonstrated the importance of the role of legitimization of bias in contributing to hate crime, a role that has been neglected in research on the United States, despite the likelihood that 1) its causes are more ubiquitous and embedded in dominant institutions and culture and 2) its effects are more sinister, longer lasting, and more harmful than retaliation against outgroups in response to improvements in their social position. Criminologists researching hate crime in the U.S. should look to the international research cited in the foregoing literature review for ways to expand the study of legitimizing forces. 
In addition to more explicit tests of legitimizing forces, future research should incorporate findings related to legitimization in individual level studies of offenders. It may be that hate offenders, as well as other offenders who specifically target marginalized groups, such as men who buy sex, are more fearful of consequences than general offenders, requiring some form of legitimization prior to acting. For example, a study found that sex buyers, a group not often targeted by law enforcement, reported that harsh or more certain penalties would alter their behavior (Farley, Golding, Matthews, Malamuth, \& Jarrett, 2015). This mirrors the evidence that some hate offenders may act only after they receive information that their social environment will shield them from consequences. The 2016 presidential election of Donald Trump likely provided such information to potential offenders; evidence showed that voters for both parties rated bias against groups that were targeted in the Trump campaign (e.g. Muslims) to be more socially acceptable after the election, despite rating their personal biases lower, while bias against groups that were not targeted (e.g. alcoholics) was rated the same before and after the election (Crandall et al., 2018).

\section{Policy Recommendations}

The role of bias legitimization at the societal, group, and individual level has a number of policy implications. Findings that hate offenders are more likely to operate in groups (Green, McFalls, et al., 2001) and that peer pressure plays a role in many offenses (Franklin, 2000), as discussed above, suggest that interventions targeting or taking advantage of peer pressure may be effective in school-aged populations. Peer pressure to 
confront bias and encourage equality could have a dampening effect on hate activities by youth. Furthermore, institutionalizing equal treatment of outgroups in schools, for example, by establishing GSAs and allowing transgender students to use bathrooms appropriate to their gender, would decrease opportunities for bias legitimization by legitimizing equality.

Beyond the classroom, the results of this study indicate that institutionalizing bias through legislation, such as requiring trans people to use the bathroom matching their birth certificate, can be expected to increase hate crimes against members of the affected groups. The results also suggest, when combined with other research findings, that biased rhetoric or actions by figures in authority may have a similar effect, by indicating to potential offenders that it is more or less safe to act on their biases. Furthermore, the effect of such bias-legitimization may last for some time. Law enforcement and public administrators should consider issuing reminders to the public of their commitment to enforce laws against hate crime before and after events anticipated to constitute biaslegitimization. Publicly asserting this commitment may also help to address the issue of underreporting of hate crimes, although addressing this issue could result in an apparent increase due to increased reporting.

Like schools, larger governing bodies and other authoritative organizations have the opportunity to restrict the effect of bias-legitimizing forces by institutionalizing or promoting equal treatment of outgroups. Legislation protecting outgroup rights has the greatest potential to reduce the effects of bias-legitimization, by preventing legislation 
promoting or codifying bias. This implication is particularly important, given the tendency of prior hate crime research to imply that legislating equal rights would tend to increase hate crime.

As von Trotha (1995) notes, the media also plays a role in bias-legitimization when it covers extreme and biased viewpoints in the same manner it covers other viewpoints. Coverage of hate groups that mirrors coverage of equal rights groups or liberal viewpoints implies that hate groups are a legitimate alternative viewpoint. Media organizations can address this by creating and following guidelines for responsible reporting. Sites such as Facebook must continue to address their role in disseminating media that may not follow responsible reporting guidelines (as well as fake news sources).

The aftermath of the 2016 presidential election shined a spotlight not only on the dearth of research into the effects of bias-legitimizing forces on hate crime, but also the lack of usable data. The UCR hate crime data continue to vary based on the whims of individual agencies, and it was not until 2015 that the UCR began to collect data on hate crimes against transgender people, who constitute one of the most victimized groups in the United States (Kenagy \& Bostwick, 2005).

Nevertheless, the current study adds to a growing body of research indicating that political actions diminishing the status of marginalized groups may have severe harmful 
effects beyond their stated intentions. While datasets such as the SPLC's hate incident collection are not available for empirical analysis comparing rates of hate crime before and after the election, the number of reported incidents occurring immediately after the election compared to the number occurring in the months following is a strong indicator that the data capture an increase in hate crime. Further, anecdotal evidence of explicitly stated causal connections to the election of President Trump in many of the hate incidents indicates that at least some portion of them is directly linked to the election result. This study supports this view empirically by analyzing data available before and after similar events. Moving forward, as policymakers consider decisions such as the legislation of public bathroom access for transgender individuals, the results of this study and others like it should inform considerations of the effects such decisions may have on the safety of members of marginalized groups beyond their ability to use public restrooms. 


\section{References}

Adamczyk, A., Gruenewald, J., Chermak, S. M., \& Freilich, J. D. (2014). The Relationship Between Hate Groups and Far-Right Ideological Violence. Journal of Contemporary Criminal Justice, 30(3), 310-332. https://doi.org/10.1177/1043986214536659

Audi, T., Scheck, J., \& Lawton, C. (2008, November 6). California Votes for Prop 8. Wall Street Journal. Retrieved from https://www.wsj.com/articles/SB122586056759900673

Badash, D. (2014, April 11). Maggie Gallagher: Prop 8 Campaign Ads Were "Not-VeryCruel.” Retrieved March 22, 2017, from http://thenewcivilrightsmovement.com/maggie-gallagher-prop-8-campaign-adswere-not-very-cruel/politics/2014/04/11/85672

Benier, K., Wickes, R., \& Higginson, A. (2016). Ethnic Hate Crime in Australia: Diversity and Change in the Neighbourhood Context. British Journal of Criminology, 56(3), 479-496.

Blalock, H. M. (1967). Toward a theory of minority-group relations. New York: New York, Wiley.

Bobo, L. (1988). Group Conflict, Prejudice, and the Paradox of Contemporary Racial Attitudes. In P. A. Katz \& D. A. (Dalmas A. Taylor (Eds.), Eliminating Racism: Profiles in Controversy (pp. 85-114). New York: New York : Plenum Press. 
Braun, R., \& Koopmans, R. (2010). The Diffusion of Ethnic Violence in Germany: The Role of Social Similarity. European Sociological Review, 26(1), 111-123.

Braun, R., \& Koopmans, R. (2014). Watch the Crowd: Bystander Responses, TrickleDown Politics, and Xenophobic Mobilization. Comparative Political Studies, 47(4), 631-658. https://doi.org/10.1177/0010414013488544

Briones-Robinson, R., Powers, R. A., \& Socia, K. M. (2016). Sexual Orientation Bias Crimes. Criminal Justice \& Behavior, 43(12), 1688-1709.

Brustein, W. I., \& King, R. D. (2004). Anti-Semitism as a response to perceived Jewish power: the cases of Bulgaria and Romania before the Holocaust *. Retrieved April 15, 2018, from http://link.galegroup.com.proxy.lib.pdx.edu/apps/doc/A127934004/ITOF?sid=go oglescholar

Chauchard, S. (2014). Can Descriptive Representation Change Beliefs about a Stigmatized Group? Evidence from Rural India. American Political Science Review, 108(2), 403-422. https://doi.org/10.1017/S0003055414000033

Crandall, C. S., Miller, J. M., \& White, M. H. (2018). Changing Norms Following the 2016 U.S. Presidential Election: The Trump Effect on Prejudice. Social Psychological and Personality Science, 9(2), 186-192. https://doi.org/10.1177/1948550617750735 
Disha, I., Cavendish, J. C., \& King, R. D. (2011). Historical Events and Spaces of Hate: Hate Crimes against Arabs and Muslims in Post-9/11 America. Social Problems, 58(1), 21-46. https://doi.org/10.1525/sp.2011.58.1.21

Falk, A., Kuhn, A., \& Zweimüller, J. (2011). Unemployment and Right-wing Extremist Crime. The Scandinavian Journal of Economics, 113(2), 260-285.

Farley, M., Golding, J. M., Matthews, E. S., Malamuth, N. M., \& Jarrett, L. (2015). Comparing Sex Buyers With Men Who Do Not Buy Sex: New Data on Prostitution and Trafficking. Journal of Interpersonal Violence, 0886260515600874. https://doi.org/10.1177/0886260515600874

FBI. (2009). Hate Crime 2008 (Uniform Crime Report). United States Department of Justice, Federal Bureau of Investigation. Retrieved from https://ucr.fbi.gov/hatecrime/2008/hate-crime-2008

Franklin, K. (2000). Antigay Behaviors Among Young Adults: Prevalence, Patterns, and Motivators in a Noncriminal Population. Journal of Interpersonal Violence, 15(4), 339-362. https://doi.org/10.1177/088626000015004001

Gladfelter, A. S., Lantz, B., \& Ruback, R. B. (2017). The Complexity of Hate Crime and Bias Activity: Variation across Contexts and Types of Bias. JQ: Justice Quarterly, 34(1), 55-83.

Green, D. P., McFalls, L. H., \& Smith, J. K. (2001). Hate Crime: An Emergent Research Agenda. Annual Review of Sociology, 27, 479-504. 
Green, D. P., \& Spry, A. D. (2014). Hate Crime Research: Design and Measurement Strategies for Improving Causal Inference. Journal of Contemporary Criminal Justice, 30(3), 228-246. https://doi.org/10.1177/1043986214536662

Green, D. P., Strolovitch, D. Z., \& Wong, J. S. (1998). Defended Neighborhoods, Integration, and Racially Motivated Crime. American Journal of Sociology, 104(2), 372-403. https://doi.org/10.1086/210042

Green, D. P., Strolovitch, D. Z., Wong, J. S., \& Bailey, R. W. (2001). Measuring Gay Populations and Antigay Hate Crime. Social Science Quarterly (Wiley-Blackwell), $82(2), 281$.

Guerra Gomez, J. A. (n.d.). US 2016 elections by County. Retrieved April 13, 2018, from http://johnguerra.co/viz/USElections2016/

Hatewatch. (2017, February 10). Post-Election Bias Incidents Up To 1,372; New Collaboration with ProPublica. Retrieved March 18, 2017, from https://www.splcenter.org/hatewatch/2017/02/10/post-election-bias-incidents1372-new-collaboration-propublica

Herek, G. M., \& Berrill, K. (1992). Hate crimes : confronting violence against lesbians and gay men. Newbury Park [Calif.]: Newbury Park Calif. : Sage Publications.

Hess, A. (2009, March 16). Prop 8: Leading Cause of California Hate Crimes?

Washington City Paper. Retrieved from //www.washingtoncitypaper.com/columns/the-sexist/blog/13117749/prop-8leading-cause-of-california-hate-crimes 
Hopkins, D. J. (2010). Politicized Places: Explaining Where and When Immigrants Provoke Local Opposition. The American Political Science Review, 104(1), 4060.

Kenagy, G. P., \& Bostwick, W. B. (2005). Health and Social Service Needs of Transgender People in Chicago. International Journal of Transgenderism, 8(2/3), 57-66. https://doi.org/10.1300/J485v08n02_06

King, R. D., \& Sutton, G. M. (2013). High Times for Hate Crimes: Explaining the Temporal Clustering of Hate-Motivated Offending. Criminology, 51(4), 871-894. https://doi.org/10.1111/1745-9125.12022

Koopmans, R., \& Olzak, S. (2004). Discursive Opportunities and the Evolution of RightWing Violence in Germany. American Journal of Sociology, 110(1), 198-230. https://doi.org/10.1086/386271

Krueger, A. B., \& Pischke, J.-S. (1997). A Statistical Analysis of Crime against Foreigners in Unified Germany. The Journal of Human Resources, 32(1), 182209. https://doi.org/10.2307/146245

Leip, D. (n.d.). 2008 Initiative General Election Results - California. Retrieved April 25, 2018, from https://uselectionatlas.org/RESULTS/state.php?fips $=6 \&$ year $=2008 \& \mathrm{f}=0 \&$ off $=67$ \&elect $=0$

Levin, J., \& McDevitt, J. (2002). Hate crimes revisited: America's war against those who are different. Boulder, Colo.: Westview. 
LeVine, R. A. (Robert A., \& Campbell, D. T. (1972). Ethnocentrism: theories of conflict, ethnic attitudes, and group behavior. New York: Wiley.

Lynch, A. M. (2008). Hating the Neighbors: The Role of Hate Crime in the Perpetuation of Black Residential Segregation. International Journal of Conflict and Violence (IJCV), 2(1), 6-27. https://doi.org/10.4119/UNIBI/ijcv.25

Lyons, C. J. (2008). Defending Turf: Racial Demographics and Hate Crime Against Blacks and Whites. Social Forces, 87(1), 357-385.

Marx, R., \& Kettrey, H. (2016). Gay-Straight Alliances are Associated with Lower Levels of School-Based Victimization of LGBTQ+ Youth: A Systematic Review and Meta-analysis. Journal of Youth \& Adolescence, 45(7), 1269-1282.

Messner, S. F., McHugh, S., \& Felson, R. B. (2004). Distinctive Characteristics of Assaults Motivated by Bias. Criminology, 42(3), 585-618.

Meuchel Wilson, M. (2014). Hate Crime Victimization, 2004-2012 - Statistical Tables (No. NCJ 244409). U.S. Department of Justice, Bureau of Justice Statistics. Miller, C., \& Werner-Winslow, A. (2016, November 29). Ten Days After: Harassment and Intimidation in the Aftermath of the Election. Retrieved March 22, 2017, from https://www.splcenter.org/20161129/ten-days-after-harassment-andintimidation-aftermath-election

Nichols, J. (2008, May 15). California Decision Makes Same-Sex Marriage a 2008 Issue. The Nation. Retrieved from https://www.thenation.com/article/californiadecision-makes-same-sex-marriage-2008-issue/ 
Perry, B. (2001). In the name of hate: understanding hate crimes. New York: Routledge.

Perry, B. (2003). Hate and bias crime: a reader. New York: Routledge.

Piatkowska, S. J. (2016). Subnational Predictors of Racially Motivated Crime: A CrossNational Multilevel Analysis. International Criminal Justice Review, 26(3), 237258. https://doi.org/10.1177/1057567716634794

Sayre, B., Bode, L., Shah, D., Wilcox, D., \& Shah, C. (2010). Agenda Setting in a Digital Age: Tracking Attention to California Proposition 8 in Social Media, Online News and Conventional News. Policy \& Internet, 2(2), 7-32. https://doi.org/10.2202/1944-2866.1040

Stotzer, R. L., \& Hossellman, E. (2012). Hate Crimes on Campus: Racial/Ethnic Diversity and Campus Safety. Journal of Interpersonal Violence, 27(4), 644-661. https://doi.org/10.1177/0886260511423249

Suttles, G. D. (1972). The social construction of communities. Chicago: Chicago, University of Chicago Press.

Tasithoughts. (2009, January 9). The GLAAD Anti-Gay Defamation List for 2008. Retrieved March 22, 2017, from https://tasithoughts.com/2009/01/09/the-glaadanti-gay-defamation-list-for-2008/

The apparent rise in hate-crime since the election is likely to be short-lived. (2016, December 10). The Economist. Retrieved from http://www.economist.com/news/united-states/21711338-if-past-any-guideapparent-rise-hate-crime-election 
Trotha, T. V. (1995). Political culture, xenophobia and the development of the violence of the radical right in the Federal Republic of Germany. Crime, Law and Social Change, 24(1), 37-47. https://doi.org/10.1007/BF01297656

Walters, M. A. (2011). A General Theories of Hate Crime? Strain, Doing Difference and Self Control. Critical Criminology, 19(4), 313-330.

https://doi.org/10.1007/s10612-010-9128-2 